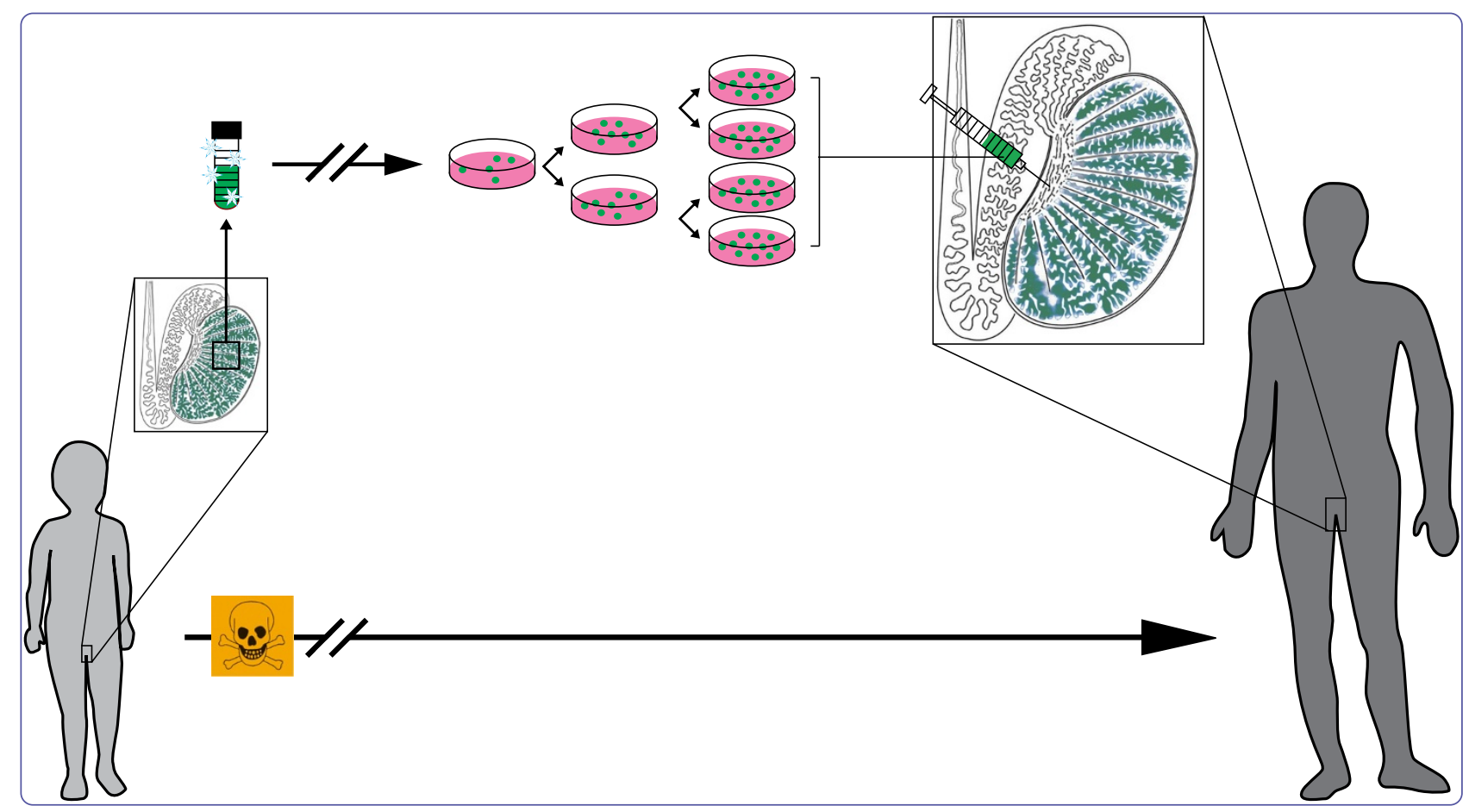

\title{
Testicular tissue cryopreservation and spermatogonial stem cell transplantation to restore fertility: from bench to bedside
}

Sadri-Ardekani and Atala 


\title{
REVIEW
}

\section{Testicular tissue cryopreservation and spermatogonial stem cell transplantation to restore fertility: from bench to bedside}

\author{
Hooman Sadri-Ardekani $i^{1,2,3^{*}}$ and Anthony Atala $a^{1,3}$
}

\begin{abstract}
Male infertility management has made significant progress during the past three decades, especially after the introduction of intracytoplasmic sperm injection in 1992. However, many boys and men still suffer from primary testicular failure due to acquired or genetic causes. New and novel treatments are needed to address these issues. Spermatogenesis originates from spermatogonial stem cells (SSCs) that reside in the testis. Many of these men lack SSCs or have lost SSCs over time as a result of specific medical conditions or toxic exposures. Loss of SSCS is critical in prepubertal boys who suffer from cancer and are going through gonadotoxic cancer treatments, as there is no option of sperm cryopresrvation due to sexual immaturity. The development of SSC transplantation in a mouse model to repopulate spermatozoa in depleted testes has opened new avenues of research in other animal models, including non-human primates. Recent advances in cryopreservation and in vitro propagation of human SSCs offer promise for human SSC autotransplantation in the near future. Ongoing research is focusing on safety and technical issues of human SSC autotransplantation. This is the time to counsel parents and boys at risk of infertility on the possibility of cryopresenving and banking a small amount of testis tissue for potential future use in SSC transplantation.
\end{abstract}

\section{Introduction}

Male infertility is a problem in 7\% of all men [1]. In 1696 sperm were first seen under the microscope and called 'homunculi' as it was believed that the sperm contained a miniature human [2]. Three centuries later, the development of intracytoplasmic sperm injection (ICSI) into an egg has revolutionized male infertility treatments as part of assisted reproductive technologies (ARTs) [3,4]. However, many men with primary testicular defects in sperm production due to genetic disorders or as a consequence of cancer treatments are still unable to become biological fathers. The identification of rat spermatogonial stem cells (SSCs) in 1971 as the foundation for spermatogenesis and sustaining male fertility [5] and the introduction of SSC transplantation in mice in 1994 opened new avenues for the field of male infertility treatments [6]. Since the discovery of the feasibility of SSC isolation and autotransplantation, it has been demonstrated in several species, including non-human primates [7]. Brian Hermann and colleagues [7] recently demonstrated successful autologous and allogeneic SSC transplantations in adult and prepubertal macaque testes that were previously rendered infertile with alkylating chemotherapy. As a result of these findings, translation of this technology to human studies is expected soon. This review focuses on several areas, including identifying patients that may benefit from testicular tissue banking to preserve SSCs, recent achievements in SSC technology, and concerns that need to be addressed before applying SSC autotransplantation in the clinical setting.

\section{Who may benefit from testicular tissue preservation and future SSC transplantation?}

\section{Malignant diseases}

Every year in the United States more than 12,000 children and adolescents aged under 20 years are diagnosed with cancer [8]. The overall cure rates of these cancer patients are approaching $80 \%$; therefore, the number of childhood cancer survivors is increasing over time [8]. 
It is known that either cancer [9] or cancer treatments [10] may adversely affect male reproduction. Chemotherapy and radiotherapy target rapidly dividing cells. These treatments not only eliminate malignant cells, but also affect germ cells. In the testis, spermatogonial cells divide rapidly and are very sensitive to cytotoxic agents, although the less active stem cells may also be killed [10]. Even in prepubescent boys, spermatogonial cells divide [11] and increase in number over time [12]. Thus, cancer treatments may result in temporary, long-term, or permanent gonadal failure in male cancer survivors [10]. In clinical practice, it is important to estimate infertility risk based on cancer type and cancer treatment protocols for each patient and consult with him and his parents (for prepubertal and adolescent patients) on his infertility risk (Tables 1 and 2) [13-15]. In adult men, semen cryopreservation before starting chemotherapy or radiotherapy is clinically approved as an efficient solution to preserve fertility by using ART procedures. Live births have been reported after insemination of stored sperm even after freezing for a period of 28 years [16]. In immature boys, spermatogenesis has not begun; therefore, storing testicular tissue prior to cancer treatments for future SSC autotransplantation could be an option (Figure 1).

\section{Non-malignant diseases need cytotoxic treatments}

In addition to malignant diseases, certain benign hematological disorders, such as myelodysplasia, sickle cell disease, aplastic anemia, thalassemia major, and Fanconi anemia, and severe autoimmune diseases unresponsive to immunosuppressive therapy, such as juvenile idiopathic arthritis, juvenile systemic lupus erythematosus, systemic sclerosis and immune cytopenias, necessitate administration of high dose chemotherapy [17-19].
This often leads to severe, dose-dependent and sometimes irreversible spermatogenic damage [20]. Dependent on treatment types (Table 2), these patients may also need to be counseled for fertility preservation.

\section{Klinefelter syndrome}

Klinefelter syndrome (KS; $47, \mathrm{XXY}$ ) is a progressive testicular failure causing small firm testes, androgen deficiency, and azoospermia [21]. This syndrome has been reported in 1 out of 660 live male births [22] and represents approximately $15 \%$ of azoospermia in infertile men [23]. KS cases have normal sexual hormones during childhood and initiate puberty at the same age as normal children; however, around mid-puberty the testes begin to deteriorate with the loss of germ cells [24]. Successful testicular sperm extraction is expected in half of KS patients [24]; a recent study showed $70 \%$ success for microscopic testicular sperm extraction in 10 cases where the males were aged between 14 and 22 years [25]. Preserving testicular tissue containing SSCs before puberty may help some KS boys in the future [26]. Less than $10 \%$ of KS is diagnosed before puberty [22]; therefore, a cost-effective and easy method (for example, PCR) to screen these children before puberty is needed.

\section{Cryptorchidism}

Failure in congenital testicular descent - cryptorchidism is the most frequent genital abnormality, affecting approximately $1 \%$ of mature births [27]. In a study of 89 cryptorchid boys who underwent bilateral testis biopsy during orchiopexy operation, $70 \%$ of scrotal testes had an impaired transformation of $A_{\text {dark }}$ spermatogonia, indicating that cryptorchidism is a bilateral disease [28]. Up to $20 \%$ of boys with unilateral cryptorchidism experience fertility problems and this figure increases up to

Table 1 Estimation of infertility risk in different types of cancer

\begin{tabular}{|c|c|c|c|c|}
\hline High risk (>80\%) & $\begin{array}{l}\text { Intermediate risk } \\
(20-80 \%)\end{array}$ & Low risk $(<20 \%)$ & $\begin{array}{l}\text { Very low/ } \\
\text { no risk }\end{array}$ & Unknown risk \\
\hline $\begin{array}{l}\text { Any cancer requiring bone marrow transplant/ } \\
\text { stem cell transplant }\end{array}$ & $\begin{array}{l}\text { Acute myeloblastic } \\
\text { leukemia }\end{array}$ & Acute lymphoblastic leukemia & $\begin{array}{l}\text { Thyroid } \\
\text { cancer }\end{array}$ & $\begin{array}{l}\text { Chronic myeloid } \\
\text { leukemia }\end{array}$ \\
\hline Brain tumor & Brain tumor & $\begin{array}{l}\text { Germ cell tumors (without } \\
\text { radiotherapy) }\end{array}$ & & Colon cancer \\
\hline Germ cell tumors & Hepatoblastoma & $\begin{array}{l}\text { Nephroblastoma (without abdominal } \\
\text { radiotherapy) }\end{array}$ & & $\begin{array}{l}\text { Gastrointestinal } \\
\text { stromal tumor }\end{array}$ \\
\hline Hodgkin lymphoma & Hodgkin lymphoma & Retinoblastoma & & $\begin{array}{l}\text { Head and neck } \\
\text { cancer }\end{array}$ \\
\hline Neuroblastoma & Neuroblastoma & Testicular cancer & & $\begin{array}{l}\text { Non-small cell lung } \\
\text { cancer }\end{array}$ \\
\hline Nephroblastoma & $\begin{array}{l}\text { Non-Hodgkin } \\
\text { lymphoma }\end{array}$ & Wilms' tumor & & Pancreatic cancer \\
\hline Non-Hodgkin lymphoma & Sarcoma & & & \\
\hline Sarcoma & Testicular cancer & & & \\
\hline Testicular cancer & Wilms' tumor & & & \\
\hline
\end{tabular}


Table 2 Estimation of infertility risk using different types of cytotoxic treatments

\begin{tabular}{|c|c|c|c|}
\hline High risk (>80\%) & Intermediate risk (20-80\%) & Low risk $(<20 \%)$ & $\begin{array}{l}\text { Very low/ } \\
\text { no risk }\end{array}$ \\
\hline $\begin{array}{l}\text { Any alkylating agent plus total body irradiation, pelvic } \\
\text { radiation, or testicular radiation (for example, procarbazine, } \\
\text { nitrogen mustard, cyclophosphamide) }\end{array}$ & $\begin{array}{l}\text { BEP } \times 2-4 \text { cycles (bleomycin, } \\
\text { etoposide, cisplatin) }\end{array}$ & $\begin{array}{l}\text { ABVD (doxorubicin, } \\
\text { bleomycin, vinblastine, } \\
\text { dacarbazine) }\end{array}$ & $\begin{array}{l}\text { Radioactive } \\
\text { iodine }\end{array}$ \\
\hline Busulfan $\left(\geq 600 \mathrm{mg} / \mathrm{m}^{2}\right)$ & Carboplatin cumulative dose $\leq 2 \mathrm{~g} / \mathrm{m}^{2}$ & $\begin{array}{l}\text { CHOP (cyclophosphamide, } \\
\text { doxorubicin, vincristine, } \\
\text { prednisone) }\end{array}$ & $\begin{array}{l}\text { Testicular } \\
\text { radiation dose } \\
(<0.2 \mathrm{~Gy})\end{array}$ \\
\hline Busulfan/cyclophosphamide & $\begin{array}{l}\text { Cisplatin cumulative dose } \\
<400 \mathrm{mg} / \mathrm{m}^{2}\end{array}$ & $\begin{array}{l}\text { COP (cyclophosphamide, } \\
\text { vincristine, prednisone) }\end{array}$ & \\
\hline $\begin{array}{l}\text { CBV (cyclophosphamide, BCNU, etoposide), BCNU cumulative } \\
\text { dose } \geq 300 \mathrm{mg} / \mathrm{m}^{2}\end{array}$ & $\begin{array}{l}\text { Testicular radiation dose (scatter } \\
\text { from abdominal/pelvic radiation) } \\
(1-6 \text { Gy) }\end{array}$ & $\begin{array}{l}\text { NOVP (mitoxantrone, } \\
\text { vincristine, vinblastine, } \\
\text { prednisone) }\end{array}$ & \\
\hline ChIVPP (chlorambucil, vinblastine, prednisone, procarbazine) & & $\begin{array}{l}\text { OEPA } \times 2 \text { cycles (vincristine, } \\
\text { etoposide, prednisone, } \\
\text { doxorubicin) }\end{array}$ & \\
\hline $\begin{array}{l}\text { ChIVPP/EVA (chlorambucil, vinblastine, prednisone, } \\
\text { procarbazine, doxorubicin, vincristine, etoposide) }\end{array}$ & & $\begin{array}{l}\text { Testicular radiation dose } \\
(0.2-0.7 \mathrm{~Gy})\end{array}$ & \\
\hline \multicolumn{4}{|l|}{$\begin{array}{l}\text { COPP } \times 6 \text { cycles (cyclophosphamide, vincristine, procarbazine, } \\
\text { prednisone) }\end{array}$} \\
\hline \multicolumn{4}{|l|}{$\begin{array}{l}\text { COPP/ABVD (cyclophosphamide, vincristine, procarabazine, } \\
\text { prednisone, doxorubicin, bleomycin, vinblastine, dacarbazine) }\end{array}$} \\
\hline \multicolumn{4}{|l|}{ Cranial/brain radiation $\geq 40$ Gy } \\
\hline \multicolumn{4}{|l|}{ Cyclophosphamide $>7.5 \mathrm{~g} / \mathrm{m}^{2}$} \\
\hline \multicolumn{4}{|l|}{ Cyclophosphamide as bone marrow transplant conditioning } \\
\hline \multicolumn{4}{|l|}{ Cyclophosphamide $\left(19 \mathrm{~g} / \mathrm{m}^{2}\right)$ plus total body irradiation } \\
\hline \multicolumn{4}{|l|}{$\begin{array}{l}\text { MOPP > } 3 \text { cycles (nitrogen mustard, vincristine, procarabazine, } \\
\text { prednisone) }\end{array}$} \\
\hline \multicolumn{4}{|l|}{$\begin{array}{l}\text { MOPP/ABVD (nitrogen mustard, vincristine, procarabazine, } \\
\text { prednisone, doxorubicin, bleomycin, vinblastine, dacarbazine) }\end{array}$} \\
\hline \multicolumn{4}{|l|}{$\begin{array}{l}\text { MVPP (nitrogen mustard, vinblastine, prednisone, } \\
\text { procarabzine) }\end{array}$} \\
\hline \multicolumn{4}{|l|}{ Procarbazine cumulative dose $\geq 4 \mathrm{~g} / \mathrm{m}^{2}$} \\
\hline \multicolumn{4}{|l|}{ Testicular radiation dose $>2.5$ Gy in adults } \\
\hline \multicolumn{4}{|l|}{ Testicular radiation dose $\geq 6$ Gy in children } \\
\hline Total body irradiation & & & \\
\hline
\end{tabular}

70\% for boys with bilateral cryptorchidism [29]. Paternity rate decreases significantly in corrected bilateral cryptorchidism (65\%) compared with unilateral cryptorchidism (89.7\%) and control men (93.2\%) [30]. Because of gradual diminishing germ cell number in these patients, it may be an option to store a portion of the testis biopsy, which can be harvested during the orchiopexy operation $[31,32]$.

\section{Testicular tissue biopsy and cryopreservation}

Testicular biopsy is an open surgical procedure and needs to be performed under general anesthesia in children. Retrieving tissue from only one testis is suggested to minimize manipulation [14] and the size of tissue may vary between 80 and $250 \mathrm{~mm}^{3}$ based on testicular size in the different age groups [33]. To minimize the risk of general anesthesia, this process should be performed at the same time as other clinical procedures (for example, bone marrow biopsy, central line replacement or orchiopexy) when possible. Based on our [34] and other groups' experiences [14,35] no major surgical complications occurred during or after testicular biopsy. Long-term follow-up of cryptorchid boys who had undergone testicular biopsy during orchiopexy showed no negative effects such as producing anti-sperm antibody or testicular scars [32]. Onset of sperm production (spermarche) is an early pubertal event. The median age of spermarche is estimated to be around 13 to 14 years, with a range between 11 and 17 years [36,37]. Thus, we recommend searching for testicular sperm in specimens from all boys aged 10 years or older, since freezing testicular sperm in glycerol-based medium [38] for use in 


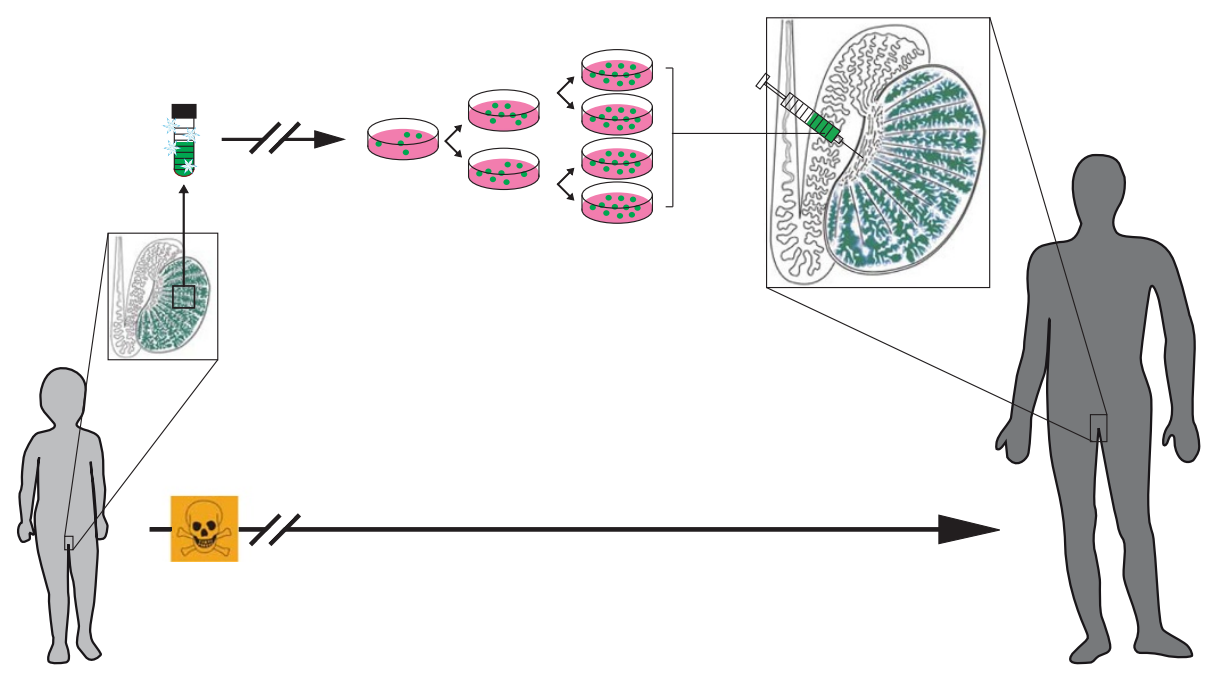

Figure 1 Schematic diagram showing testicular tissue cryopreservation and future spermatogonial stem cell autotransplantation to restore male fertility in high-risk patients.

ICSI is available in most ART laboratories [39]. Protocols for freezing small samples ( 2 to $4 \mathrm{~mm}^{3}$ ) of immature human testicular tissue using dimethyl sulfoxide (DMSO) as the main cryoprotectant showed good structural integrity of testicular tubules, and pre-tubular and intra-tubular cells after thawing $[11,40]$. Xenotransplantation of cultured DMSO frozen SSCs from immature human testes showed the migration ability of SSCs to the base membrane of mouse seminiferous tubules without differentiation to mature germ cells [34]. The same cryopreservation method has been used for storing mice SSCs for longer than 14 years. Fertile offspring were derived after transplanting these long-term stored SSCs [41]. Our current testicular tissue banking protocol at Wake Forest Baptist Health for boys at risk of infertility indicates that, if testicular sperm are found, then half of the tissue will be frozen (Figure 2) in routinely used egg yolk-glycerol-based cryopreservation medium to preserve sperms for ICSI and the other half will be frozen to preserve the SSCs in DMSO-based medium for future culture and transplantation.

\section{Isolation and in vitro propagation of spermatogonial stem cells} Spermatogonial stem cell isolation

The first successful isolation of human SSCs was reported from six infertile adult men in 2002 [42]. In that study, isolated human SSCs were able to colonize and survive for 6 months in mice recipient testes even after a freeze-thaw procedure. Numbers of colonized human SSCs in mouse seminiferous tubules were evaluated up to 6 months after transplantation. Observation of clusters of human SSCs about 1 month after transplantation suggested the proliferation of these cells in mouse testes.
Human cells remained up to 6 months in mouse testes, although their numbers significantly decreased by 2 months after transplantation. No meiotic differentiation of human germ cells in mouse testes was observed [42]. Recently, in a study of prepubertal boys diagnosed with cancer, SSCs were isolated and demonstrated stem cell activity after xenotransplantation to mouse testes similar to that seen in human adult SSCs [43]. This study used biopsies from nine boys aged 2 to 10 years and a preliminary estimation indicated that spermatogonial cells comprised about $3 \%$ of the cell population from these biopsies [43]. The number of SSCs in the testis is very low. In mouse testis only $0.03 \%$ of germ cells and $1.25 \%$ of spermatogonial cells are estimated to be stem cells $[44,45]$. In contrast to rodents, human spermatogonial cells can be divided into two subgroups, $A_{\text {pale }}$ and $A_{\text {dark }}$, according to their nuclear staining with hematoxylin after Bouin's fixation [46]. $A_{\text {dark }}$ spermatogonia in normal circumstances are quiescent cells and are thought to be reserve (stem) cells [45]. Current SSC isolation methods are based on two-step enzymatic digestion [47]. Investigators have enriched human spermatogonial cells using magnetic activated cell sorting (MACS) with markers such as GFRA1 ${ }^{+}$[48], GPR125+ [49], SSEA4 ${ }^{+}$[50], and HLA-ABC ${ }^{-} / \mathrm{CD}^{+}$[51] or using fluorescence-activated cell sorting (FACS) by isolating

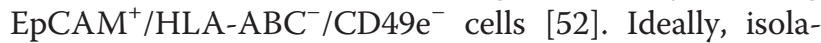
tion of pure SSCs is expected, but no specific marker has been found to identify the stem cells in testis [53]. Finding suitable marker(s) is a formidable task [54].

\section{In vitro propagation}

In immature boys, the size of the testis is small with a rare population of SSCs; therefore, isolation of these cells from a 

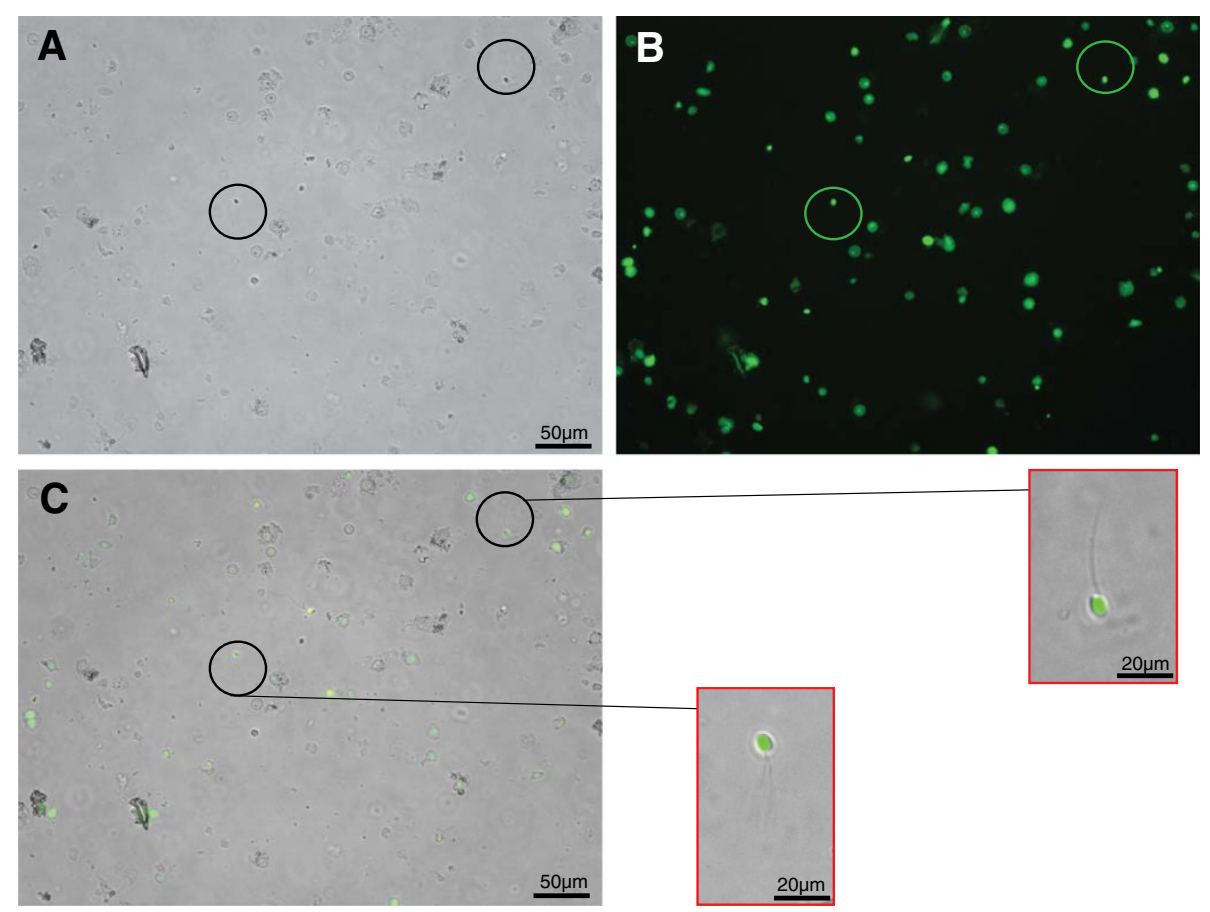

Figure 2 Testicular sperm viability after freeze and thaw. Live sperms were stained with Calcein (green fluorescent). (A) Bright field; (B) fluorescent; (C) merged. A LIVE/DEAD Sperm Viability Kit (L-7011 Invitrogen, Life Technologies Ltd, Paisley, UK) was used for staining thawed testicular sperms. Testicular tissue for research was obtained from transplant donors through the National Disease Research Interchange.

small testicular biopsy yields a very limited number of stem cells. Based on animal studies, SSC transplantation efficiency depends on the number of transplanted SSCs, with an almost linear correlation [55]. Therefore, increasing the number of SSCs in vitro is necessary before transplantation. Successful in vitro culturing of SSCs has been reported in several species, including mouse [56,57], rat [58], bovine [59], hamster [60], and dog [61]. Recently, in vitro propagation of human SSCs from both adult [62] and prepubertal [34] testes was established. In these systems, human SSCs are supported by a feeder layer from the same patients' testicular somatic cells. Germ line stem cell clusters formed within 2 to 4 weeks of culture (Figure 3). Xenotransplantation of human testicular cells from different time points of in vitro culture into nude mice testes showed that human SSCs could be maintained in vitro for more than 15 weeks with a doubling time of 3 to 7 days [34,62]. Optimization of this culture system based on US Food and Drug Administration regulations and current good tissue practice requirements are imperative before use in a clinical application.

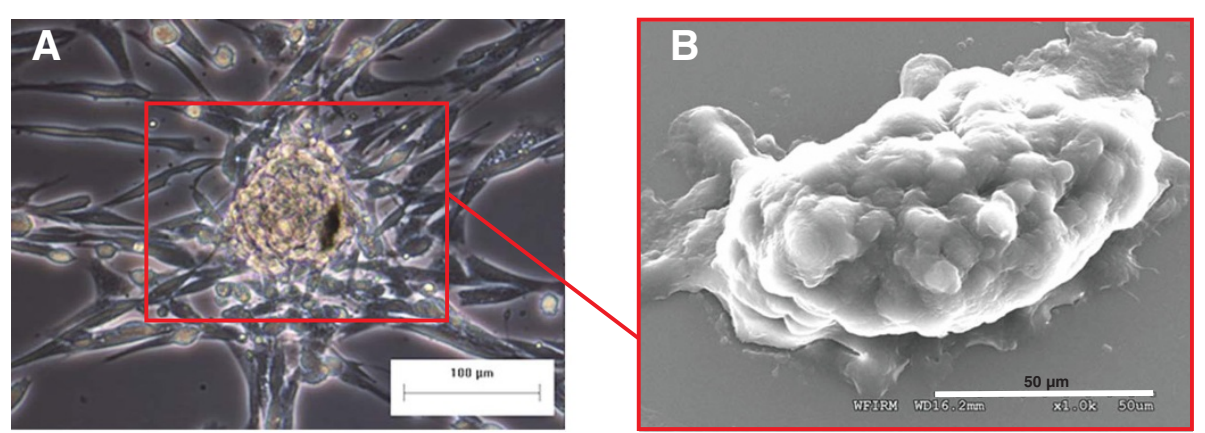

Figure $3 \mathrm{Germ}$ line stem cells cluster in human testicular cell culture. The presence of these germ line clusters has been described previously [34,62]. (A) Bright field; (B) scanning electron microscopy. Testicular tissue for research was obtained from transplant donors through the National Disease Research Interchange. 


\section{Safety and technical issues of spermatogonial stem cell transplantation}

\section{Genetics and epigenetics stability}

Harvesting testicular tissue via biopsy, freezing and thawing the tissue, and cell isolation and culturing are all processes that may affect the integrity of SSCs. Alterations in manipulated cells may occur in the genome, in the epigenome, or in both [63-65]. There are reports that show the genetic stability of other stem cell populations during in vitro culture $[66,67]$. Since SSCs are the cells that transmit genetic information to the next generations, concerns about SSC stability are much more important than those about somatic cells. A study on transplantation of isolated SSCs from C57Bl/WBRe donor mouse (without culturing) to the testes of $\mathrm{W} / \mathrm{Wv}$ mice [68] showed normal development (length and weight) compared with controls for first and second generation offspring. DNA extracted from posttransplantation spermatozoa, liver, kidney and placenta revealed no differences in methylation patterns of genes for Igf2, Peg1 and a-Actin between offspring of transplanted and control mice [68]. Kanatsu-Shinohara and colleagues [69] showed that in vitro expansion of mouse SSCs over 24 months continued with normal karyotype and stable androgenetic imprinting. The offspring of recipient mice were fertile and also had a normal imprinting pattern. However, genetic alterations or epigenetic patterns of isolated and cultured human SSCs have not yet been determined.

\section{Contamination with cancer cells}

The most important concern regarding SSC autotransplantation is the risk of reintroducing malignant cells to the cancer survivor. This is very important in non-solid hematopoietic cancers, as malignant cells can migrate through the blood circulation and infiltrate the testis [70]. It has been demonstrated that intraluminal injection of as few as 20 leukemia cells into the testes of recipient rats could induce disease relapse in three out of five animals [71]. A few studies have tried to eliminate malignant cells from mouse, non-human primate and human testicular cell suspensions [52,72-75]. These studies used different surface markers for MACS or FACS of contaminating cells. Currently there is no specific marker for purifying SSCs [76] and these cells share several biomarkers with other stem cells and cancer cells, especially hematopoietic cells [77]; therefore, the sorting methods have not yielded tumor cell-free populations. The most recent study attempting to remove human leukemia cells from testicular cells using the markers $\mathrm{EpCAM}^{+} / \mathrm{HLA}$ $\mathrm{ABC}^{-} / \mathrm{CD} 49 \mathrm{e}^{-}$showed some progress [52]; however, the bioassay method used for post-sorting detection of leukemia cells was not sensitive enough ( $0.2 \%$ sensitivity) and the false negative rate was high $(>60 \%)$ [52,75].
Using other detection methods with higher sensitivity, such as minimal residual disease PCR (up to 0.0001\% sensitivity) [78] or tumor cell imaging (to detect as few as 3 to 10 cells) [79] are recommended. Our recently published pilot study using minimal residual disease PCR to track leukemia cells in a human SSC in vitro propagation system showed leukemia cells were eliminated after 26 days of co-culturing with spermatogonial cells [80].

\section{Spermatogonial stem cell injection}

A mouse model for injection of SSCs into the testis is possible with the microinjection of the SSCs into the seminiferous tubules, into the rete testis, or into the efferent duct [81]. However, in larger animals like bovine, monkey and even human cadaver, studies have shown that injection of SSCs into the seminiferous tubules or the efferent duct was not successful [82]. This is because of high resistance of the lamina propria and coiled seminiferous tubules in larger animals. The most promising models for SSC injection into human testis is ultrasoundguided injection into the rete testis [82,83]. In the most recent study on autopsied human testes, injecting 8 to 16 million cells in a volume of 800 to $1,400 \mu \mathrm{l}$ via a 23 gauge needle could fill up to $40 \%$ of the seminiferous tubules in 1 to 2 minutes [83]. There is only one reported clinical trial of SSC autotransplantation, in seven cancer survivors [84], but the details of this study and patient follow-up data have not been published. Further investigation is necessary to optimize the injection procedure as well as compare ultrasound-guided versus open surgery for SSC transplantation.

\section{Points of view of patients and their families}

It is important to understand how patients and their families feel about fertility preservation and testicular tissue banking. Psychosocial studies clearly demonstrate a high incidence of negative reactions to infertility and its negative effect on overall life satisfaction and wellbeing [85]. The main target groups for testicular tissue cryopreservation for future SSC autotransplantation are children, which presents difficulties for discussion of future reproduction and family planning. Childhood cancer survivors who transit into adulthood express concerns about fertility and fathering children [86]. At least half of the parents of boys who suffer from cancer agree with performing testicular biopsy to preserve SSCs $[35,87,88]$. Parents choose fertility preservation even if the chance of infertility is low $(\leq 20 \%)$ and the success rate of future SSCs transplantation will also be low $(\leq 20 \%)$ [88]; these findings show the great importance of fertility preservation for families. 


\section{Follow-up after spermatogonial stem cell transplantation}

Both childhood and adult cancer survivors are interested in understanding the risks of passing on genetic damage capable of causing adverse outcomes in their children [89]. Reviewing a cohort of 8,670 children born between 1994 and 2004 with a paternal history of cancer versus $17,690,795$ children without a paternal history of cancer showed a higher incidence of major congenital abnormalities in the offspring of male cancer survivors (3.7 out of 100) than in those of fathers with no history of cancer (3.2 out of 100) [90]. Around 5\% of children (508 out of 8,670 ) were conceived using ART, either in vitro fertilization (5\%) or ICSI (95\%), with the higher risk of abnormalities with in vitro fertilization (two times more) compared to ICSI or natural conception [90]. Previous studies have shown no significant differences in the outcome of pregnancy in cancer survivors [91,92]. However, ICSI (when it is required) and prenatal diagnosis tests (for example, amniocentesis) during pregnancy in cancer survivors may overcome this small risk.

As clinical trials of SSC autotransplantation are initiated, it is necessary to monitor the health of recipient men. Like other ART treatments, pregnancy and the offspring should be followed for any major abnormalities.

\section{Conclusion}

SSCs are germ line stem cells that reside in the basement membrane of the seminiferous tubule in the testis. They are the foundation of spermatogenesis for the production of sperm after puberty. In 1994 Brinster's group [6] reported a SSC assay in mice that shows the ability of these cells to generate a colony of spermatogenesis after transplantation in the seminiferous tubules of a recipient male. Since then, researchers in the field of male infertility have searched for new clinical tools to help more men who suffer from primary testicular failure. Immature boys at risk of losing their SSCs, mostly cancer patients, are the main target group that may benefit from testicular tissue cryopreservation and SSC autotransplantation. Progress in the field of SSC transplantation in animal studies, including non-human primates, has been shown. Effective freezing methods for adult and prepubertal testicular tissue are available and recently in vitro propagation of human SSCs with the ability to colonize the basement membrane of testes has been established. Therefore, translation of SSC autotransplantation to humans is expected to be possible in the near future. The families of prepubertal and adolescent male patients are eagerly awaiting fertility preservation by means of testicular tissue banking and utilization in future clinical applications. Simultaneous to the ongoing research on safety and technical issues of human SSC autotransplantation, it is necessary to counsel parents and the boys at risk of infertility on the possibility of cryopreserving a small testis biopsy in experimental SSC banking.

Note: This article is part of a thematic series on Stem cells in genitourinary regeneration edited by John Jackson. Other articles in the series can be found online at http://stemcellres.com/series/ genitourinary.

\section{Abbreviations}

ART: Assisted reproductive technology; DMSO: Dimethyl sulfoxide; FACS: Fluorescence-activated cell sorting; ICSI: Intracytoplasmic sperm injection; KS: Klinefelter syndrome; MACS: Magnetic activated cell sorting; PCR: Polymerase chain reaction; SSC: Spermatogonial stem cell.

Competing interests

The authors declare that they have no competing interests.

\section{Acknowledgements}

We would like to thank Drs John D Jackson and Sean V Murphy for editorial assistance. We acknowledge use of tissues procured by the National Disease Research Interchange (NDRI) with support from NIH grant 5U42RR006042. This work was supported by Erret-Fisher Foundation grant GTS 3679.

\section{Author details}

${ }^{1}$ Wake Forest Institute of Regenerative Medicine (WFIRM), Wake Forest School of Medicine, Winston-Salem, North Carolina 27101, USA.

${ }^{2}$ Reproductive Biotechnology Research Center, Avicenna Research Institute, ACECR, Tehran 1177-19615, Iran. ${ }^{3}$ Department of Urology, Wake Forest School of Medicine, Winston-Salem, North Carolina 27101, USA.

\section{Published: 28 May 2014}

\section{References}

1. Krausz C: Male infertility: pathogenesis and clinical diagnosis. Best Pract Res Clin Endocrinol Metab 2011, 25:271-285.

2. Ruestow EG: Images and ideas: Leeuwenhoek's perception of the spermatozoa. J History Biol 1983, 16:185-224.

3. Palermo G, Joris H, Devroey P, Van Steirteghem AC: Pregnancies after intracytoplasmic injection of single spermatozoon into an oocyte. Lancet 1992, 340:17-18.

4. Anawalt BD: Approach to male infertility and induction of spermatogenesis. J Clin Endocrinol Metab 2013, 98:3532-3542.

5. Huckins C: The spermatogonial stem cell population in adult rats. I. Their morphology, proliferation and maturation. Anat Rec 1971, 169:533-557.

6. Brinster RL, Zimmermann JW: Spermatogenesis following male germ-cell transplantation. Proc Natl Acad Sci U S A 1994, 91:11298-11302.

7. Hermann BP, Sukhwani M, Winkler F, Pascarella JN, Peters KA, Sheng Y, Valli H, Rodriguez M, Ezzelarab M, Dargo G, Peterson K, Masterson K, Ramsey C, Ward T, Lienesch M, Volk A, Cooper DK, Thomson AW, Kiss JE, Penedo MC, Schatten GP, Mitalipov S, Orwig K: Spermatogonial stem cell transplantation into rhesus testes regenerates spermatogenesis producing functional sperm. Cell Stem Cell 2012, 11:715-726.

8. O'Conner-Von S: Coping with cancer: a web-based educational program for early and middle adolescents. J Pediatr Oncol Nurs 2009, 26:230-241.

9. Agarwal A, Allamaneni SS: Disruption of spermatogenesis by the cancer disease process. J Natl Cancer Inst Monogr 2005, 34:9-12.

10. Meistrich ML: Effects of chemotherapy and radiotherapy on spermatogenesis in humans. Fertil Steril 2013, 100:1180-1186.

11. Wyns C, Van Langendonckt A, Wese FX, Donnez J, Curaba M: Long-term spermatogonial survival in cryopreserved and xenografted immature human testicular tissue. Hum Reprod 2008, 23:2402-2414.

12. Paniagua R, Nistal M: Morphological and histometric study of human spermatogonia from birth to the onset of puberty. J Anat 1984, 139:535-552. 
13. Wallace WH, Anderson RA, Irvine DS: Fertility preservation for young patients with cancer: who is at risk and what can be offered? Lancet Oncol 2005, 6:209-218.

14. Wyns C, Curaba M, Petit S, Vanabelle B, Laurent P, Wese JF, Donnez J: Management of fertility preservation in prepubertal patients: 5 years' experience at the Catholic University of Louvain. Hum Reprod 2011, 26:737-747.

15. Fertile Hope: Fertility risk calculator. http://www.fertilehope.org/tool-bar/ risk-calculator.cfm.

16. Feldschuh J, Brassel J, Durso N, Levine A: Successful sperm storage for 28 years. Fertil Steril 2005, 84:1017.

17. Anserini P, Chiodi S, Spinelli S, Costa M, Conte N, Copello F, Bacigalupo A: Semen analysis following allogeneic bone marrow transplantation. Additional data for evidence-based counselling. Bone Marrow Transplant 2002, 30:447-451.

18. Berthaut I, Guignedoux G, Kirsch-Noir F, de Larouziere V, Ravel C, Bachir D, Galactéros F, Ancel PY, Kunstmann JM, Levy L, Jouannet P, Girot R, Mandelbaum J. Influence of sickle cell disease and treatment with hydroxyurea on sperm parameters and fertility of human males. Haematologica 2008, 93:988-993.

19. Oktay K, Oktem O: Fertility preservation medicine: a new field in the care of young cancer survivors. Pediatr Blood Cancer 2009, 53:267-273.

20. David J, Vouyiouka O, Ansell BM, Hall A, Woo P: Amyloidosis in juvenile chronic arthritis: a morbidity and mortality study. Clin Exp Rheumatol 1993, 11:85-90.

21. Klinefelter $H$, Reifenstein $E$, Albright F: Syndrome characterized by gynecomastia, aspermatogenesis without A-Leydigism, and increased excretion of folliclestimulating hormone. J Clin Endocrinol Metab 1942, 2:615-627.

22. Bojesen A, Juul S, Gravholt CH: Prenatal and postnatal prevalence of Klinefelter syndrome: a national registry study. J Clin Endocrinol Metab 2003, 88:622-626.

23. Hofherr SE, Wiktor AE, Kipp BR, Dawson DB, Van Dyke DL: Clinical diagnostic testing for the cytogenetic and molecular causes of male infertility: the Mayo Clinic experience. J Assist Reprod Genet 2011, 28:1091-1098.

24. Aksglaede $L$, Juul $A$ : Testicular function and fertility in men with Klinefelter syndrome: a review. Eur J Endocrinol 2013, 168:R67-R76.

25. Mehta A, Bolyakov A, Roosma J, Schlegel PN, Paduch DA: Successful testicular sperm retrieval in adolescents with Klinefelter syndrome treated with at least 1 year of topical testosterone and aromatase inhibitor. Fertil Steril 2013, 100:970-974.

26. Wyns C, Curaba M, Vanabelle B, Van Langendonckt A, Donnez J: Options for fertility preservation in prepubertal boys. Hum Reprod Update 2010, 16:312-328.

27. Schroeder JA, Siegmund HI, Roesch W, Hadziselimovic F, Hofstaedter F: Male infertility: assessment of juvenile testicular dysfunction and risk for malignancy in cryptorchid boys based on resin section evaluation. Ultrastruct Pathol 2013, 37:373-377.

28. Hadziselimovic F, Hoecht B: Testicular histology related to fertility outcome and postpubertal hormone status in cryptorchidism. Klin Padiatr 2008, 220:302-307.

29. Cortes D: Cryptorchidism - aspects of pathogenesis, histology and treatment. Scand J Urol Nephrol Suppl 1998, 196:1-54.

30. Lee PA: Fertility after cryptorchidism: epidemiology and other outcome studies. Urology 2005, 66:427-431.

31. Kvist K, Thorup J, Byskov AG, Hoyer PE, Mollgard K, YDing Andersen C: Cryopreservation of intact testicular tissue from boys with cryptorchidism. Hum Reprod 2006, 21:484-491.

32. Patel RP, Kolon TF, Huff DS, Carr MC, Zderic SA, Canning DA, Snyder HM 3rd: Testicular microlithiasis and antisperm antibodies following testicular biopsy in boys with cryptorchidism. J Urol 2005, 174:2008-2010. discussion 2010.

33. Goede J, Hack WW, Sijstermans K, van der Voort-Doedens LM, Van der Ploeg T, Meij-de Vries A, de Waal HA D-v: Normative values for testicular volume measured by ultrasonography in a normal population from infancy to adolescence. Horm Res Paediatr 2011, 76:56-64.

34. Sadri-Ardekani $H$, Akhondi MA, van der Veen F, Repping S, van Pelt AM: In vitro propagation of human prepubertal spermatogonial stem cells. JAMA 2011, 305:2416-2418.

35. Ginsberg JP, Carlson CA, Lin K, Hobbie WL, Wigo E, Wu X, Brinster RL, Kolon TF: An experimental protocol for fertility preservation in prepubertal boys recently diagnosed with cancer: a report of acceptability and safety. Hum Reprod 2009, 25:37-41.

36. Kulin HE, Frontera MA, Demers LM, Bartholomew MJ, Lloyd TA: The onset of sperm production in pubertal boys. Relationship to gonadotropin excretion. Am J Dis Child 1989, 143:190-193.
37. Schaefer F, Marr J, Seidel C, Tilgen W, Scharer K: Assessment of gonadal maturation by evaluation of spermaturia. Arch Dis Child 1990, 65:1205-1207.

38. Crabbe E, Verheyen G, Tournaye H, Van Steirteghem A: Freezing of testicular tissue as a minced suspension preserves sperm quality better than whole-biopsy freezing when glycerol is used as cryoprotectant. Int J Androl 1999, 22:43-48.

39. Hourvitz A, Goldschlag DE, Davis OK, Gosden LV, Palermo GD, Rosenwaks Z: Intracytoplasmic sperm injection (ICSI) using cryopreserved sperm from men with malignant neoplasm yields high pregnancy rates. Fertil Steril 2008, 90:557-563.

40. Keros V, Hultenby K, Borgstrom B, Fridstrom M, Jahnukainen K, Hovatta O: Methods of cryopreservation of testicular tissue with viable spermatogonia in pre-pubertal boys undergoing gonadotoxic cancer treatment. Hum Reprod 2007, 22:1384-1395.

41. Wu X, Goodyear SM, Abramowitz LK, Bartolomei MS, Tobias JW, Avarbock MR, Brinster RL: Fertile offspring derived from mouse spermatogonial stem cells cryopreserved for more than 14 years. Hum Reprod 2013, 27:1249-1259

42. Nagano M, Patrizio $P$, Brinster RL: Long-term survival of human spermatogonial stem cells in mouse testes. Fertil Steril 2002, 78:1225-1233.

43. Wu X, Schmidt JA, Avarbock MR, Tobias JW, Carlson CA, Kolon TF, Ginsberg JP, Brinster RL: Prepubertal human spermatogonia and mouse gonocytes share conserved gene expression of germline stem cell regulatory molecules. Proc Natl Acad Sci U S A 2009, 106:21672-21677.

44. Tegelenbosch RA, de Rooij DG: A quantitative study of spermatogonial multiplication and stem cell renewal in the $\mathrm{C} 3 \mathrm{H} / 101 \mathrm{~F} 1$ hybrid mouse. Mutat Res 1993, 290:193-200.

45. Aponte PM, van Bragt MP, de Rooij DG, van Pelt AM: Spermatogonial stem cells: characteristics and experimental possibilities. Apmis 2005, 113:727-742.

46. Clermont Y: Spermatogenesis in man. A study of the spermatogonial population. Fertil Steril 1966, 17:705-721.

47. van Pelt AM, Morena AR, van Dissel-Emiliani FM, Boitani C, Gaemers IC, de Rooij DG, Stefanini M: Isolation of the synchronized A spermatogonia from adult vitamin A-deficient rat testes. Biol Reprod 1996, 55:439-444.

48. Gassei K, Ehmcke J, Schlatt S: Efficient enrichment of undifferentiated GFR alpha 1+ spermatogonia from immature rat testis by magnetic activated cell sorting. Cell Tissue Res 2009, 337:177-183.

49. He Z, Kokkinaki M, Jiang J, Dobrinski I, Dym M: Isolation, characterization, and culture of human spermatogonia. Biol Reprod 2010, 82:363-372.

50. Izadyar F, Wong J, Maki C, Pacchiarotti J, Ramos T, Howerton K, Yuen C, Greilach S, Zhao HH, Chow M, Chow YC, Rao J, Barritt J, Bar-Chama N, Copperman A: Identification and characterization of repopulating spermatogonial stem cells from the adult human testis. Hum Reprod 2011, 26:1296-1306

51. Zohni $K$, Zhang $X$, Tan SL, Chan P, Nagano M: CD9 is expressed on human male germ cells that have a long-term repopulation potential after transplantation into mouse testes. Biol Reprod 2012, 87:27.

52. Dovey SL, Valli H, Hermann BP, Sukhwani M, Donohue J, Castro CA, Chu T, Sanfilippo JS, Orwig KE: Eliminating malignant contamination from therapeutic human spermatogonial stem cells. J Clin Invest 2013, 123:1833-1843.

53. Brinster RL: Male germline stem cells: from mice to men. Science 2007, 316:404-405.

54. Kanatsu-Shinohara M, Shinohara T: Spermatogonial stem cell self-renewal and development. Annu Rev Cell Dev Biol 2013, 29:163-187.

55. Dobrinski I, Ogawa T, Avarbock MR, Brinster RL: Computer assisted image analysis to assess colonization of recipient seminiferous tubules by spermatogonial stem cells from transgenic donor mice. Mol Reprod Dev 1999, 53:142-148.

56. Kanatsu-Shinohara M, Miki H, Inoue K, Ogonuki N, Toyokuni S, Ogura A, Shinohara T: Long-term culture of mouse male germline stem cells under serum- or feeder-free conditions. Biol Reprod 2005, 72:985-991.

57. Kanatsu-Shinohara M, Ogonuki N, Inoue K, Miki H, Ogura A, Toyokuni S, Shinohara T: Long-term proliferation in culture and germline transmission of mouse male germline stem cells. Biol Reprod 2003, 69:612-616.

58. Hamra FK, Chapman KM, Nguyen DM, Williams-Stephens AA, Hammer RE, Garbers DL: Self renewal, expansion, and transfection of rat spermatogonial stem cells in culture. Proc Natl Acad Sci U S A 2005, 102:17430-17435.

59. Aponte PM, Soda T, Teerds KJ, Mizrak SC, van de Kant HJ, de Rooij DG: Propagation of bovine spermatogonial stem cells in vitro. Reproduction 2008, 136:543-557. 
60. Kanatsu-Shinohara M, Muneto T, Lee J, Takenaka M, Chuma S, Nakatsuji N, Horiuchi T, Shinohara T: Long-term culture of male germline stem cells from hamster testes. Biol Reprod 2008, 78:611-617.

61. Kim Y, Turner D, Nelson J, Dobrinski I, McEntee M, Travis AJ: Production of donor-derived sperm after spermatogonial stem cell transplantation in the dog. Reproduction 2008, 136:823-831.

62. Sadri-Ardekani H, Mizrak SC, van Daalen SK, Korver CM, Roepers-Gajadien HL, Koruji M, Hovingh S, de Reijke TM, de la Rosette JJ, van der Veen F, de Rooij DG, Repping S, van Pelt AM: Propagation of human spermatogonial stem cells in vitro. JAMA 2009, 302:2127-2134.

63. Maitra A, Arking DE, Shivapurkar N, Ikeda M, Stastny V, Kassauei K, Sui G, Cutler DJ, Liu Y, Brimble SN, Noaksson K, Hyllner J, Schulz TC, Zeng X, Freed WJ, Crook J, Abraham S, Colman A, Sartipy P, Matsui S, Carpenter M, Gazdar AF, Rao M, Chakravarti A: Genomic alterations in cultured human embryonic stem cells. Nat Genet 2005, 37:1099-1103.

64. Liu AM, Qu WW, Liu X, Qu CK: Chromosomal instability in in vitro cultured mouse hematopoietic cells associated with oxidative stress. Am J Blood Res 2012, 2:71-76.

65. Skinner MK: Environmental epigenomics and disease susceptibility. EMBO Rep 2011, 12:620-622.

66. Bernardo ME, Zaffaroni N, Novara F, Cometa AM, Avanzini MA, Moretta A, Montagna D, Maccario R, Villa R, Daidone MG, Zuffardi O, Locatelli F: Human bone marrow derived mesenchymal stem cells do not undergo transformation after long-term in vitro culture and do not exhibit telomere maintenance mechanisms. Cancer Res 2007, 67:9142-9149.

67. Wang L, Yang Y, Zhu Y, Ma X, Liu T, Zhang G, Fan H, Ma L, Jin Y, Yan X, Wei J, Li Y: Characterization of placenta-derived mesenchymal stem cells cultured in autologous human cord blood serum. Mol Med Rep 2012, 6:760-766.

68. Goossens E, De Rycke M, Haentjens P, Tournaye H: DNA methylation patterns of spermatozoa and two generations of offspring obtained after murine spermatogonial stem cell transplantation. Hum Reprod 2009, 24:2255-2263.

69. Kanatsu-Shinohara M, Ogonuki N, Iwano T, Lee J, Kazuki Y, Inoue K, Miki H, Takehashi M, Toyokuni S, Shinkai Y, Oshimura M, Ishino F, Ogura A, Shinohara T: Genetic and epigenetic properties of mouse male germline stem cells during long-term culture. Development 2005, 132:4155-4163.

70. Akhtar M, Ali MA, Burgess A, Aur RJ: Fine-needle aspiration biopsy (FNAB) diagnosis of testicular involvement in acute lymphoblastic leukemia in children. Diagn Cytopathol 1991, 7:504-507.

71. Jahnukainen K, Hou M, Petersen C, Setchell B, Soder O: Intratesticular transplantation of testicular cells from leukemic rats causes transmission of leukemia. Cancer Res 2001, 61:706-710.

72. Fujita K, Tsujimura A, Miyagawa Y, Kiuchi H, Matsuoka Y, Takao T, Takada S, Nonomura N, Okuyama A: Isolation of germ cells from leukemia and lymphoma cells in a human in vitro model: potential clinical application for restoring human fertility after anticancer therapy. Cancer Res 2006, 66:11166-11171.

73. Geens M, Van de Velde H, De Block G, Goossens E, Van Steirteghem A, Tournaye $H$ : The efficiency of magnetic-activated cell sorting and fluorescence-activated cell sorting in the decontamination of testicular cell suspensions in cancer patients. Hum Reprod 2007, 22:733-742.

74. Geens M, Goossens E, Tournaye H: Cell selection by selective matrix adhesion is not sufficiently efficient for complete malignant cell depletion from contaminated human testicular cell suspensions. Fertil Steril 2011, 95:787-791.

75. Hermann BP, Sukhwani M, Salati J, Sheng Y, Chu T, Orwig KE: Separating spermatogonia from cancer cells in contaminated prepubertal primate testis cell suspensions. Hum Reprod 2011, 26:3222-3231.

76. Dym M, Kokkinaki M, He Z: Spermatogonial stem cells: mouse and human comparisons. Birth Defects Res C Embryo Today 2009, 87:27-34.

77. Spangrude GJ, Heimfeld S, Weissman IL: Purification and characterization of mouse hematopoietic stem cells. Science 1988, 241:58-62.

78. Jolkowska J, Derwich K, Dawidowska M: Methods of minimal residual disease (MRD) detection in childhood haematological malignancies. J Appl Genet 2007, 48:77-83.

79. Rabinovich BA, Ye Y, Etto T, Chen JQ, Levitsky HI, Overwijk WW, Cooper LJ, Gelovani J, Hwu P: Visualizing fewer than 10 mouse T cells with an enhanced firefly luciferase in immunocompetent mouse models of cancer. Proc Natl Acad Sci U S A 2008, 105:14342-14346.

80. Sadri-Ardekani $\mathrm{H}$, Homburg CH, van Capel TM, van den Berg $\mathrm{H}$, van der Veen F, van der Schoot CE, van Pelt AM, Repping S: Eliminating acute lymphoblastic leukemia cells from human testicular cell cultures: a pilot study. Fertil Steril 2014, 101:1072-1078.

81. Ogawa T, Arechaga JM, Avarbock MR, Brinster RL: Transplantation of testis germinal cells into mouse seminiferous tubules. Int J Dev Biol 1997, 41:111-122.

82. Schlatt S, Rosiepen G, Weinbauer GF, Rolf C, Brook PF, Nieschlag E: Germ cell transfer into rat, bovine, monkey and human testes. Hum Reprod 1999, 14:144-150.

83. Faes K, Tournaye H, Goethals L, Lahoutte T, Hoorens A, Goossens E: Testicular cell transplantation into the human testes. Fertil Steril 2013, 100:981-988 e984.

84. Radford JA: Is prevention of sterility possible in men? Ann Oncol 2000, 11(Suppl 3):173-174

85. Boivin J, Takefman J, Braverman A: The fertility quality of life (FertiQoL) tool: development and general psychometric properties. Hum Reprod 2011, 26:2084-2091.

86. Zebrack BJ, Casillas J, Nohr L, Adams H, Zeltzer LK: Fertility issues for young adult survivors of childhood cancer. Psycho-Oncology 2004, 13:689-699.

87. van den Berg H, Repping S, van der Veen F: Parental desire and acceptability of spermatogonial stem cell cryopreservation in boys with cancer. Hum Reprod 2007, 22:594-597.

88. Sadri-Ardekani H, Akhondi MM, Vossough P, Maleki H, Sedighnejad S, Kamali K, Ghorbani B, van Wely M, van der Veen F, Repping S: Parental attitudes toward fertility preservation in boys with cancer: context of different risk levels of infertility and success rates of fertility restoration. Fertil Steril 2013, 99:796-802.

89. Signorello LB, Friedman DL, Boice JD Jr: Congenital abnormalities: a legacy of cancer treatment? J Natl Cancer Inst 2011, 103:358-359.

90. Stahl O, Boyd HA, Giwercman A, Lindholm M, Jensen A, Kjaer SK, Anderson H, Cavallin-Stahl E, Rylander L: Risk of birth abnormalities in the offspring of men with a history of cancer: a cohort study using Danish and Swedish national registries. J Nat/ Cancer Inst 2011, 103:398-406.

91. Byrne J, Rasmussen SA, Steinhorn SC, Connelly RR, Myers MH, Lynch CF, Flannery J, Austin DF, Holmes FF, Holmes GE, Strong LC, Mulvihill JJ: Genetic disease in offspring of long-term survivors of childhood and adolescent cancer. Am J Hum Genet 1998, 62:45-52.

92. Chow EJ, Kamineni A, Daling JR, Fraser A, Wiggins CL, Mineau GP, Hamre MR, Severson RK, Drews-Botsch C, Mueller BA: Reproductive outcomes in male childhood cancer survivors: a linked cancer-birth registry analysis. Arch Pediatr Adolesc Med 2009, 163:887-894.

\section{$10.1186 /$ scrt457}

Cite this article as: Sadri-Ardekani and Atala: Testicular tissue cryopreservation and spermatogonial stem cell transplantation to restore fertility: from bench to bedside. Stem Cell Research \& Therapy 2014, 5:68 